\title{
PERANAN TOKSIN YANG DIHASILKAN OLEH BOTRYODIPLODIA THEOBROMAE DALAM MENIMBULKAN PENYAKIT DIPLODIA PADA BEBERAPA JENIS JERUK
}

\author{
Salamiah $^{1}$
}

\begin{abstract}
Role of toxin produced by Botryodiplodia theobromae causes Diplodia Bark Diseases on some citrus. The purpose of the research was to study the role of toxin produced by Botryodiplodia theobromae causes diplodia bark diseases on some citrus. Research was conducted from March through November 2007. The experiment was done at the laboratory and at a glass house of the Department of Plant Pests and Diseases of the Faculty of Agriculture and the laboratory of the Faculty of Science and Mathematics Lambung Mangkurat University in Banjarbaru. For a leaf-necrosis bioassay of crude toxin production, the surfaces of the leaves were scratched near the center with a needle, and culture filtrate samples (50 $\mu 1)$ were placed on each wounded site. Treated leaves were incubated in a moist chamber with light at $26^{\circ} \mathrm{C}$ for 4 days, and toxin activity was determined by induction of veinal necrosis on the seven susceptible cultivar of citrus. The results of the experiment showed that the $B$. theobromae pathogens produced the toxin. The crude toxin was bioassayed for leaf necrosis to determine their ability to produce toxin. Culture filtrates of the isolate were highly toxic only on five susceptible citrus leaves siam Banjar citrus, sweet orange, lime, kaffir lime, and sour lime, indicating that the B. theobromae can produced toxin. Pathogenicity and toxin production of $B$. theobromae did not differ among different cultivar. While, no necrotic symptom produces on the pummelo and sunkist. Toxin production of $B$. theobromae produced during spore germination.
\end{abstract}

Keywords: Siam Banjar Citrus, Toxin, diplodia diseases, Botryodiplodia theobromae

\section{PENDAHULUAN}

Jeruk Siam Banjar merupakan salah satu komoditas andalan Kalimantan Selatan yang bernilai tinggi. Kendala utama dalam usahatani jeruk ini adalah gangguan Botryodiplodia theobromae Pat. penyebab penyakit kulit diplodia. Penyakit ini dapat mematikan tanaman. Sampai saat ini pengendalian penyakit kulit diplodia di Kalimantan Selatan masih belum efektif dan efisien. Salah satu pendekatan yang bisa dilakukan adalah mempelajari faktor-faktor yang mempengaruhi patogenisitas patogen.

Toksin sebagai salah satu senyawa beracun yang berperan dalam menimbulkan penyakit tanaman adalah suatu mekanisme yang sudah terbukti bagaimana patogen menyeleksi tanaman inangnya (Yoder, 1980; Nishimura \& Kohmoto, 1983; Scheffer \& Livingston, 1984; Walton, 1996). Toksin yang dihasilkan patogen ada dua macam yakni, toksin spesifik inang atau HostSpecific Toxin (HST) dan toksin non spesifik inang atau Non-Host Selective Toxin (NHST).
Studi tentang HST dan penyakit tanaman memberikan kontribusi yang mendasar untuk memahami proses, regulasi kerentanan dan ketahanan tanaman terhadap penyakit, dasar-dasar biokimia tanaman melalui penggunaannya sebagai inhibitor metabolit spesifik, struktur dan organisasi lintasan metabolit sekunder, organisasi genom fungi serta munculnya ras patogen yang baru (Kohmoto \& Otani, 1991).

Penyakit tanaman, khususnya yang disebabkan oleh jamur adalah faktor pembatas utama dalam produksi tanaman. Di antara banyak strategi yang tersedia untuk pengendalian penyakit, salah satunya adalah penggunaan tanaman yang mempunyai resistensi genetik. Cara ini terbukti sangat efektif dan aman terhadap lingkungan (Agrios, 1997).

Gen yang berperan dalam ketahanan tanaman terhadap patogen mempunyai peranan penting dalam pengembangan kultivar yang tahan terhadap patogen (Agrios, 1997; Flor, 1971). Akan tetapi, pengertian mendasar bagaimana tanaman tahan terhadap penyakit

\footnotetext{
${ }^{1}$ Jurusan Hama dan Penyakit Tumbuhan, Fakultas Pertanian, Universitas Lambung Mangkurat,

Jl. Jend. A. Yani Kotak Pos 1028, Banjarbaru, Tel \& Fax. 0511-4777392. E-mail: salamiah_amsya@yahoo.com
} 
masih sangat kurang. Studi mengenai peranan toksin dalam menimbulkan penyakit tanaman adalah dasar untuk mengerti kerentanan tanaman terhadap penyakit dan bagaimana mengendalikannya dengan memanipulasi petogen itu sendiri (Dewey et al., 1988).

Dari jenis organisme pengganggu tanaman yang ditemukan, B. theobramae paling ditakuti oleh petani jeruk di Kalimantan Selatan (BPTPH Kalimantan Selatan, 2003), karena serangannya dapat mengakibatkan kematian ranting, cabang, batang tanaman, bahkan menyebabkan kematian tanaman.

Sampai saat ini pengendalian penyakit diplodia masih mengandalkan pestisida kimiawi seperti Topsin. Penggunaan Topsin sebenarnya sudah tidak dianjurkan lagi karena efektivitasnya sangat rendah (Muhammad Ali, Kepala Sub Bagian Perlindungan Tanaman, Dinas Pertanian Tanaman Pangan, Propinsi Kalimantan Selatan, komunikasi pribadi). Alternatif lain adalah penggunaan komponen pengendalian penyakit yang ramah lingkungan seperti penggunaan pestisida botani dan agensia antagonis. Secara in vitro kedua metode pengendalian ini efektif menekan perkembangan patogen penyebab penyakit diplodia pada jeruk, namun secara in vivo kedua metode pengendalian ini tidak efektif (Salamiah \& Melanie, 2004; Salamiah \& Rahmah, 2004). Alternatif pengendalian lainnya adalah penggunaan varietas tahan, tetapi sampai saat ini belum ditemukan satu jenis jeruk pun yang tahan terhadap penyakit diplodia ini.

Host-specific AM-toxin telah berhasil dimanfaatkan untuk menskrining tanaman yang tahan terhadap Alternaria alternata patotipe apel (Hiroki Tabira, Komunikasi Pribadi). Penggunaan isolat avirulen atau virulensinya yang sangat rendah dilaporkan efektif sebagai agen pengendali hayati (Ogoshi, 1985; Kardin, 1977). Isolat ini ada yang bersifat antagonis terhadap patogen, menghambat pertumbuhan miselium melalui antibiosis maupun melalui aktivitas peroksidase yang mereka keluarkan (Khan et al., 1992).

Dengan mempelajari toksin yang dihasilkan oleh patogen penyebab penyakit Diplodia, melakukan mutasi, selanjutnya aplikasi toksin defisien mutan diharapkan dapat menginduksi sistem pertahanan tanaman terhadap patogen. Dengan dimilikinya pengetahuan dasar tentang mekanisme interaksi antara patogen dan tanaman, diharapkan semakin banyak alternatif pengendalian penyakit tanaman yang berwawasan lingkungan yang bisa dipilih untuk diterapkan.

Penelitian ini bertujuan untuk mempelajari peranan toksin yang dihasilkan oleh $B$. theobromae yang berasal dari jeruk siam Banjar dalam menimbulkan penyakit diplodia pada beberapa jenis tanaman jeruk.

\section{METODE PENELITIAN}

Penelitian ini dilaksanakan di Laboratorium Fitopatologi dan rumah kaca Jurusan Hama dan Penyakit Tumbuhan Fakultas Pertanian dan Laboratorium Dasar FMIPA Unlam Banjarbaru, mulai Maret - Nopember 2007.

Isolat patogen yang digunakan dalam penelitian ini didapatkan dengan mengisolasi penyebab penyakit dari tanaman jeruk siam Banjar yang memperlihatkan gejala penyakit kulit diplodia basah dan kering yang diambil dari desa Sungai Kambat, Kabupaten Barito Kuala Kalimantan Selatan yang merupakan salah satu sentra produksi jeruk siam Banjar dan banyak terserang penyakit ini.

Untuk mengidentifikasi dan mempelajari sifat-sifat biologis dan patologis toksin dan mengidentifikasi toksin yang dihasilkan oleh patogen penyebab penyakit diplodia telah dilakukan isolasi patogen, isolasi crude toxin yang dihasilkan oleh patogen, dan karakterisasi biologis toksin.

\section{Isolasi Patogen}

Patogen diisolasi dengan cara memotong bagian tanaman yang terserang penyakit kulit diplodia, kemudian dicelupkan dalam $\mathrm{NaClO} 1 \%$ selama 10 menit. Potongan batang, cabang atau ranting kemudian dicuci dengan air steril sebanyak tiga kali kemudian dikeringkan dengan kertas hisap steril dalam cawan petri. Setelah kering dipotong kecil-kecil sebesar $1 \times 3 \mathrm{~cm}$, potongan tersebut dimasukkan dalam kotak biakan berisi kertas hisap steril yang telah dibasahi. Potongantanaman yang bergejala diletakkan di atas gelas objek atau pengganjal lainnya untuk menghindarkan kontak langsung dengan kertas penghisap basah. Jika hal ini terjadi maka sampel akan mudah busuk dan akan mudah ditumbuhi kontaminan.

Isolat patogen dalam kotak biakan ini kemudian diinkubasikan pada suhu kamar selama satu minggu sampai terjadi sporulasi pada permukaan batang, cabang atau ranting tanaman. Kelembaban kotak biakan harus selalu dipelihara dengan selalu menambahkan sejumlah air steril ke dalam kertas penghisap dalam kotak biakan. Spora yang tumbuh dipindahkan ke media PDA untuk selanjutnya dibuat biakan murni.

Seluruh isolat dimurnikan dengan isolasi spora tunggal (single spore isolation) berdasarkan metode yang diuraikan oleh Huang \& Kohmoto (1991) dan 
disimpan dalam $20 \%$ glycerol pada $-80^{\circ} \mathrm{C}$ sebagai stok biakan sampai siap untuk digunakan. Isolasi spora tunggal metode Huang \& Kohmoto (1991) dilakukan dengan jalan menumbuhkan konidia ke dalam media PDA. Konidia dipanen dari hasil biakan murni yang telah diregenerasikan dalam cawan petri dengan jalan menambahkan akuades steril. Konsentrasi konidia yang ditumbuhkan adalah $1 \times 10^{2}$ konidia/ml. Satu ml suspensi konidia diteteskan di atas media PDA, kemudian diratakan dengan jarum ose steril, setelah itu diinkubasikan dalam inkubator dengan suhu $26^{\circ} \mathrm{C}$. Pengamatan dilakukan setiap hari dengan menggunakan mikroskop cahaya. Jika konidia mulai berkecambah, satu persatu dari konidia tersebut segera dipindahkan ke dalam cawan petri yang telah berisi media PDA baru. Satu cawan petri bisa dianggap sebagai spora tunggal dan dapat dibuat biakan murni.

\section{Isolasi crude toxin yang dihasilkan oleh patogen} Isolasi crude toxin yang dihasilkan oleh petogen dilakukan dengan membiakkan patogen $B$. theobromae pada media Potato Dextrose Broth (PDB). Media PDB dibuat dengan mencampur ekstrak kentang yang diperoleh dari $250 \mathrm{~g}$ kentang, dipotong kecil-kecil sebesar $1 \mathrm{~cm}^{2}$ kemudian dikukus dengan pemanasan sedang. Ekstrak kentang yang telah diperoleh dicampur dengan $20 \mathrm{~g}$ dextrose dan 11 aqudest, kemudian dipanaskan. Setelah tercampur merata, media tersebut dituang ke dalam labu erlenmenyer, lalu mulut labu ditutup dengan kapas dan aluminium foil. Media disterilkan dengan menggunakan otoklaf selama 15-20 menit pada tekanan 15 psi.

Lima potongan kecil miselium dari isolat murni dimasukkan ke dalam labu erlenmeyer $250 \mathrm{ml}$ yang berisi medium PDB sebanyak $50 \mathrm{ml}$ kemudian diinkubasikan pada suhu kamar selama satu bulan. Jika patogen tersebut menghasilkan toksin, maka toksin akan dilepas ke medium cair dan toksin dapat diambil dari medium cair tersebut.

Biakan B. theobromae yang telah diinkubasikan dipanen dengan melakukan filtrasi dengan menggunakan empat lapis kain saring (muslin cloth) dan dua lapis miracloth. $\mathrm{pH}$ filtrat biakan diatur menjadi 5,5 dengan menambahkan $10 \% \mathrm{NaH}_{2} \mathrm{PO}_{4}$ dan diaduk dengan resin Amberlite XAD-2 (Organo Co. Ltd., Tokyo) selama 4 jam untuk mengadsorbsi toksin. Toksin yang telah diikat oleh resin dengan jalan adsorbsi tadi, dipak dalam column, dicuci dengan air, dan dielusi dengan 5 volume methanol. Langkah ini diulang sebanyak 3 kali untuk meningkatkan jumlah toksin yang dapat dikoleksi. Untuk mendapatkan bahan aktif (toksin) dilakukan pengeringan dengan menggunakan rotary evaporator.

\section{Karakterisasi biologis toksin}

Aktifitas biologi dan spesifikasi inang dari toksin yang telah diisolasi dideterminasi dengan leaf necrosis assay pada tanaman inang (Kohmoto, 1992; Salamiah et al., 2001a \& 2001b). Daun dan cabang jeruk muda yang telah dikoleksi dari lapang dicuci bersih. Permukaan daun dan cabang diberi pelukaan sedikit dengan menggunakan pisau kecil. Sampel toksin sebanyak $20 \mu \mathrm{l}$ diaplikasikan pada bagian yang telah dilukai. Pengujian akan dilakukan dengan beberapa pengenceran. Sampel tanaman yang telah diberi perlakuan toksin ditempatkan dalam kotak biakan pada suhu $25^{\circ} \mathrm{C}$ selama 24 jam. Masing-masing perlakuan diulang sebanyak tiga kali.

Peranan toksin dalam infeksi. Untuk menguji peranan toksin secara patologis selama proses infeksi, uji faktor penginduksi infeksi dilaksanakan berdasarkan metode yang diuraikan oleh Kohmoto (1992). Toksin yang telah diisolasi dari tanaman sakit diambil dan dikoleksi dalam erlenmeyer. Toksin ini diuji peranannya dalam proses infeksi dengan jalan menginokulasikan ke daun dan batang tanaman jeruk. Sebagai kontrol perlakuan, daun dan batang tanaman jeruk juga diinokulasi dengan isolat murni yang telah diisolasi dari tanaman sakit. Jika kedua inokulasi ini menghasilkan gejala yang sama, maka dapat disimpulkan bahwa toksin yang dihasilkan mempunyai peranan dalam proses infeksi. Jika tanaman yang diberi toksin tidak menghasilkan gejala yang sama dengan tanaman yang diberi isolat patogen, maka kemungkinannya adalah toksin tersebut tidak berperan dalam proses infeksi tapi mungkin berperan dalam menyebabkan kerentanan tanaman melalui aktivitasnya yang lain, bukan dalam proses infeksi.

Uji toksin saat perkecambahan spora. Sebagian HST dihasilkan pada saat spora atau konidia berkecambah (Otani et al., 1995). Analisis toksin yang dihasilkan pada saat perkecambahan spora atau konidia dilaksanakan berdasarkan metode yang diuraikan oleh Kohmoto et al. (1993). Daun dan batang jeruk sehat yang telah dikoleksi dari lapangan, dibersihkan dari kotoran kemudian dilakukan sterilisasi permukaan dengan menggunakan alkohol $70 \%$ sebanyak satu kali, kemudian dicuci dengan akuades sebanyak tiga kali, dimasukkan dalam kotak biakan yang telah diberi spun di bagian alasnya. Suspensi spora diambil sebanyak $1 \mathrm{ml}$, 
kemudian diinokulasikan ke daun dan batang jeruk yang telah dipersiapkan dalam kotak biakan. Setiap satu jam di sekitar tempat inokulasi dilakukan pengambilan cairan yang ada. Koleksi cairan diinokulasikan kembali ke daun dan batang jeruk sehat yang telah dipersiapkan di dalam moisture chamber. Jika cairan yang diinokulasikan ini menimbulkan gejala penyakit kulit diplodia, maka dapat disimpulkan bahwa patogen mengeluarkan toksin pada saat konidia mulai berkecambah.

Uji toksin dalam cairan Interseluler. Penelitian ini untuk mengetahui apakah toksin dihasilkan dan dilepaskan bersama cairan interselular dalam bagian tanaman sakit. Ifs diisolasi berdasarkan metode Hammond-Kosack (1992) yang telah dimodifikasi (Singh, 2000). Bagian tanaman sakit dikoleksi dari lapangan, kemudian dihaluskan dengan blender. Ke dalam bagian tanaman sakit yang halus ditambahkan akuades steril kemudian disaring dengan kain kasa steril. Cairan perasan bagian tanaman sakit ini diinokulasikan ke batang dan daun jeruk sehat yang telah dikoleksi dari lapangan dan ditempatkan dalam kotak biakan. Jika toksin dilepaskan dalam jaringan tanaman sakit, maka hasil inokulasi akan segera memperlihatkan gejala sakit setelah tiga hari diinkubasikan pada suhu kamar.

Uji patogenisitas dan karakterisasi patologis toksin. Toksin yang dihasilkan dalam media PDB diinokulasikan ke daun jeruk sehat untuk melihat peranannya dalam patogenisitas. Jika toksin berperan dalam menimbulkan penyakit, maka daun jeruk akan memperlihatkan gejala yang sama dengan jika diinokulasi dengan propagul patogen (hifa atau spora).

\section{HASIL DAN PEMBAHASAN}

Isolasi Patogen. Tanaman jeruk yang diinokulasi dengan isolat $B$. theobromae yang diperoleh dari lapangan, pada batangnya menunjukkan adanya lukaluka atau jalur-jalur yang sempit sehingga pada kulit terjadi luka-luka yang tidak teratur (Gambar 1A). Isolat yang diperoleh diinokulasikan pada tanaman jeruk. Gejala mulai nampak 64 hari setelah diinokulasi dengan B. theobromae (Gambar 1B). Gejala lanjut diperlihatkan dengan terbentuknya gom berwarna keemasan sampai hitam (Gambar 1C).

Dari hasil identifikasi diyakini bahwa patogen yang diisolasi dari tanaman jeruk siam Banjar adalah $B$. theobromae dengan konidia berbentuk lonjong dengan satu sekat transversal. Konidia hasil isolasi dari tanaman jeruk siam Banjar disajikan pada Gambar 2.
Botryodiplodia mempunyai konidia yang sederhana, berbentuk lonjong dengan satu sekat transversal (Barnett \& Hunter, 1972). Hasil isolasi patogen dari tanaman jeruk memperlihatkan bentuk konidia yang sama dengan keterangan dari Barnett dan Hunter (1972), sehingga dapat disimpulkan bahwa patogen yang digunakan dalam penelitian adalah B. theobromae penyebab penyakit kulit diplodia pada jeruk siam Banjar.

Isolasi crude toxin yang dihasilkan oleh patogen. Hasil pengamatan menunjukkan bahwa toksin yang diinokulasikan pada daun segar menghasilkan nekrosis pada daun. Gejala nekrosis teramati 3 hari setelah inokulasi (Gambar 3).

Karena permukaan dinding kulit batang jeruk keras, maka kemungkinan besar patogen mensekresikan enzim pada daerah penetrasi dengan tujuan untuk melembutkan atau melunakkan kulit batang tanaman jeruk. Pengujian toksin pada daun jeruk dilakukan dengan meletakkan daun jeruk di dalam kotak biakan, kemudian diberi perlakuan dengan akuades steril, PDB murni, PDB hasil penyaringan (yang mengandung toksin), dan diinokulasi dengan isolat $B$. theobromae. Semua perlakuan diawali dengan melukai permukaan daun dengan peniti dengan membuat goresan halus. Hal ini dimaksudkan untuk memudahkan masuknya toksin dan patogen ke dalam jaringan tanaman. Akuades steril dan PDB murni digunakan sebagai kontrol, untuk membuktikan bahwa akuades steril dan PDB sebagai media tidak menimbulkan gejala nekrosis. PDB hasil penyaringan yang mengandung toksin didapatkan dengan cara menyaring PDB yang diinokulasi dengan miselium $B$. theobromae dan telah diinkubasi selama satu bulan pada suhu kamar. Jika tidak ditumbuhi oleh B. theobromae, maka PDB hasil saring tersebut bebas dari miselium dan spora $B$. theobromae. Hasil pengujian memperlihatkan bahwa daun yang diaplikasi dengan toksin mengalami nekrosis. Gejala ini sama dengan gejala yang dialami oleh daun yang diinokulasi dengan patogen B. theobromae. Daun yang diberi akuades steril dan PDB murni tidak mengalami nekrosis.

Toksin merupakan suatu senyawa yang dihasilkan oleh mikroorganisme dan bersifat toksik (racun) pada tanaman. Toksin melukai sel inang, salah satu caranya adalah dengan mempengaruhi permeabilitas membran sel atau dengan menon-aktifkan atau menghambat enzim dan kemudian menghentikan reaksi enzim yang terkait (Agrios, 1997). Wujud toksin yang didapat masih berupa crude toxin, bisa berupa enzim atau inhibitor. Interaksi antara patogen dan inang, 


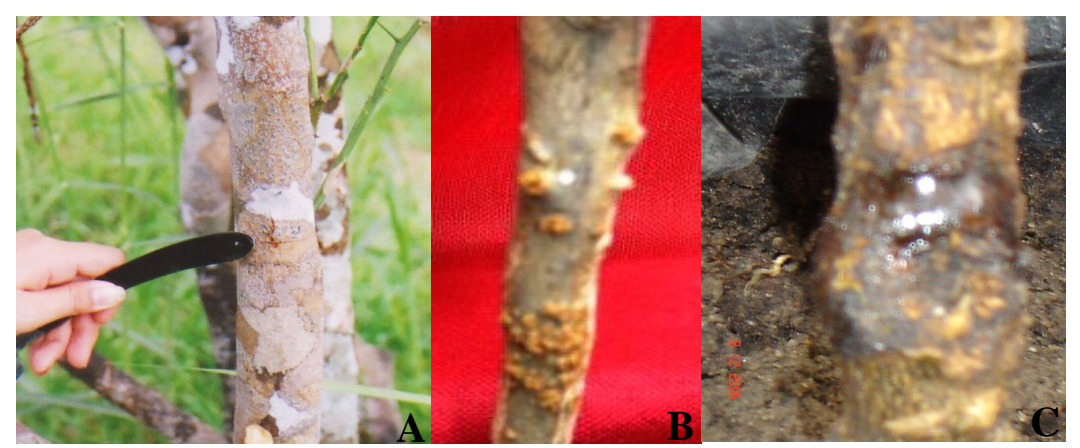

Gambar 1. Gejala serangan B. theobromae pada tanaman jeruk A. Gejala awal B. Kulit batang jeruk mulai pecah dan benjolan mulai tampak C. Gejala serangan yang sudah lanjut

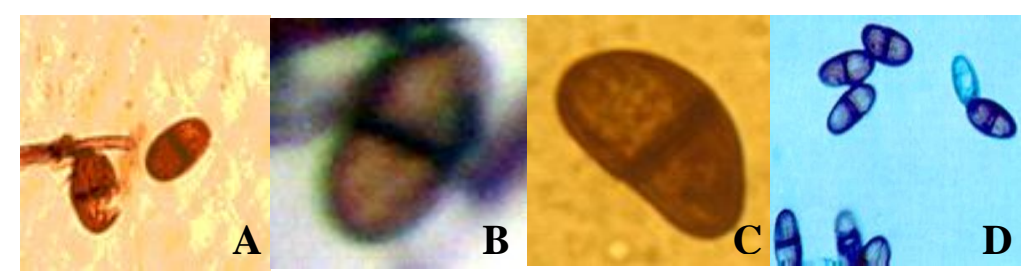

Gambar 2. Bentuk-bentuk konidia B. theobromae. A-C. Konidia hasil isolasi dari tanaman jeruk siam Banjar, D. Konidia hasil isolasi Balai Pengkajian Teknologi Pertanian Karangploso Malang (1997)

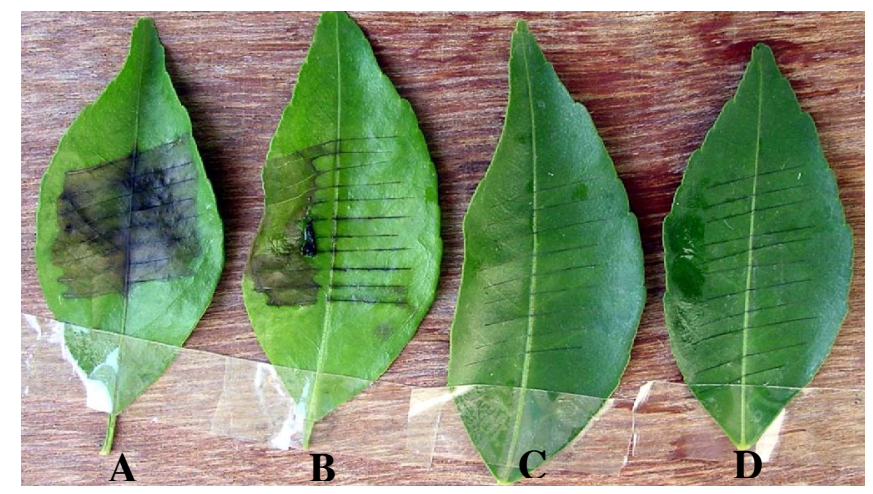

Gambar 3. Hasil pengujian inokulasi toksin pada daun jeruk siam Banjar. A. Toksin B. Isolat C. PDB D. Aquadest (Pengamatan dilakukan 5 hari setelah diberi perlakuan).

terjadi apabila inang mengenal patogen. Jika inang mengenal patogen, maka inang akan memberikan respon dengan melakukan reaksi hipersensitif, dan inang akan mengeluarkan senyawa anti fungi (Kohmoto \& Otani, 1991).

Senyawa ini bersifat toksik terhadap patogen. Pada daerah yang diinfeksi oleh patogen akan terjadi nekrosis. Reaksi hipersensitif yang terjadi akan menghentikan perkembangan patogen.

Patogen mengeluarkan toksin yang akan menyebabkan nekrosis. Nekrosis ini mengakibatkan kerusakan seluruh jaringan sel, dan perkembangan patogen akan semakin meningkat. 


\section{Karakterisasi Biologis Toksin}

Aktivitas biologi dan spesifikasi inang dari toksin yang telah diisolasi dideterminasi dengan leafnecrosis assay pada tanaman inang.

Peranan toksin dalam infeksi. Untuk melihat peranan toksin secara patologis selama proses infeksi, dilakukan pengamatan terhadap uji faktor penginduksi infeksi.
Dari tujuh varietas jeruk (Siam Banjar, jeruk bali, jeruk irisan, jeruk nipis, sunkist, jeruk purut dan jeruk sambal), yang diberi perlakuan dengan crude toxin, tidak ada satu varietas jerukpun yang memperlihatkan gejala nekrosis. Hal ini diduga bahwa toksin hanya diperlukan untuk membantu patogen masuk ke dalam sel, namun tidak berperan dalam proses infeksi dalam tanaman dan toksin tersebut tidak diproduksi lagi di dalam tanaman.

Tabel 1. Toksisitas crude toxin dari Botryodiplodia theobromae (3 hari setelah aplikasi toksin)

\begin{tabular}{lccccc}
\hline \multirow{2}{*}{ Kultivar Jeruk } & \multicolumn{7}{c}{ Ulangan } \\
\cline { 2 - 6 } & 1 & 2 & 3 & 4 & 5 \\
\hline Siam Banjar & - & - & + & - & - \\
Bali & - & - & - & - & - \\
Irisan & + & - & + & - & - \\
Nipis & + & + & + & + & - \\
Sunkist & - & - & - & - & - \\
Purut & + & + & - & + & + \\
Sambal & + & - & - & - & + \\
\hline
\end{tabular}

Tabel 2. Toksisitas crude toxin dari Botryodiplodia theobromae (4 hari setelah aplikasi toksin)

\begin{tabular}{lccccc}
\hline \multirow{2}{*}{ Kultivar Jeruk } & \multicolumn{5}{c}{ Ulangan } \\
\cline { 2 - 6 } & 1 & 2 & 3 & 4 & 5 \\
\hline Siam Banjar & + & + & + & + & + \\
Bali & - & - & - & - & - \\
Irisan & + & - & + & - & - \\
Nipis & + & + & + & + & - \\
Sunkist & - & - & - & - & - \\
Purut & + & + & - & + & + \\
Sambal & + & - & - & - & + \\
\hline
\end{tabular}

Tabel 3. Toksisitas crude toxin dari Botryodiplodia theobromae (5 hari setelah aplikasi toksin)

\begin{tabular}{lccccc}
\hline Kultivar Jeruk & \multicolumn{5}{c}{ Ulangan } \\
\cline { 2 - 6 } & 1 & 2 & 3 & 4 & 5 \\
\hline Siam Banjar & + & + & + & + & + \\
Bali & - & - & - & - & - \\
Irisan & + & - & + & - & - \\
Nipis & + & + & + & + & + \\
Sunkist & - & - & - & - & - \\
Purut & + & + & - & + & + \\
Sambal & + & + & - & - & + \\
\hline
\end{tabular}

Keterangan:

$+=$ Nekrosis

- = Tidak terjadi nekrosis 
Uji toksin saat perkecambahan spora. Produksi toksin pada saat patogen melakukan perkecambahan diamati dengan tujuan untuk melihat apakah patogen menghasilkan suatu ekskret berupa senyawa metabolit sekunder yang berfungsi membantu proses infeksi pada saat patogen mulai memasuki sel tanaman. Hasil pengamatan terhadap gejala nekrosis pada delapan varietas daun jeruk yang diuji dapat dilihat pada Tabel 1, 2, dan 3.

Dari Tabel 1, 2, dan 3 terlihat bahwa gejala nekrosis pada jeruk yang diuji mulai tampak 3 hari setelah aplikasi toksin. Hal ini menandakan bahwa $B$. theobromae yang dibiakkan dalam media PDB menghasilkan toksin pada saat patogen berkecambah. Hal ini mendukung pendapat Otani et al. (1995) yang menyatakan bahwa toksin tidak murni dilepaskan oleh patogen pada saat melakukan perkecambahan. Toksin yang telah dilepaskan ke dalam media cair dapat diisolasi dengan jalan melakukan penyaringan. Senyawa metabolit sekunder yang dihasilkan oleh $B$. theobromae diyakini berupa toksin karena pada saat diinokulasikan ke tanaman, dengan konsentrasi yang sangat rendah 0,01 ppm terbukti berperan dalam menimbulkan penyakit pada tanaman jeruk. Gejala nekrosis ditemukan pada jeruk Siam Banjar, jeruk irisan, jeruk purut, jeruk sambal dan jeruk nipis (Gambar 4).

Sedangkan jeruk bali dan sunkist, sampai 5 hari pengamatan nekrosis tidak ditemukan (Gambar 5).

Tidak munculnya nekrosis pada jeruk bali dan sunkist menandakan bahwa crude toxin yang dihasilkan oleh $B$. theobromae tidak toksik pada jeruk bali dan sunkist.

Pengamatan dilakukan sampai 5 hari setelah aplikasi toksin karena sebagian besar daun yang diaplikasi dengan toksin gejala nekrosis sudah mencapai seluruh permukaan daun.

Uji toksin dalam cairan Interseluler. Hasil pengamatan terhadap daun yang telah diinokulasi dengan cairan interseluler yang telah dikoleksi dari bagian tanaman sakit, menunjukkan semua daun yang diinokulasi tidak memperlihatkan gejala nekrosis. Hal ini menunjukkan bahwa toksin diproduksi oleh patogen hanya pada saat diperlukan untuk melakukan penetrasi pada permukaan tanaman yakni pada saat dia melakukan perkecambahan.

Uji patogenisitas dan karakterisasi patologis toksin. Hasil inokulasi crude toxin pada jeruk siam Banjar memperlihatkan bahwa daun jeruk yang diinokulasi dengan toksin menghasilkan gejala nekrosis. Gejala ini juga diperlihatkan oleh daun jeruk yang diinokulasi dengan isolat $B$. theobromae. Sedangkan daun jeruk yang diinokulasi dengan media PDB dan akuades, gejala nekrosis tidak muncul (Gambar 3).

Pada jeruk siam Banjar, kemungkinan besar tanaman tidak mengenal patogen B. theobromae Pat.. Oleh karena itu, jeruk siam Banjar tidak melakukan mekanisme reaksi hipersensitif untuk mencegah perkembangan patogen $B$. theobromae. Pada saat patogen melakukan penetrasi pada permukaan tanaman, patogen menghasilkan toksin yang menyebabkan kerusakan jaringan tanaman yang dapat diamati dari gejala nekrosis yang diakibatkannya pada daun yang diberi perlakuan dengan toksin. Jeruk siam Banjar mempunyai reseptor terhadap toksin yang dihasilkan B. theobromae. Adanya reseptor pada jeruk siam bisa dibuktikan dengan adanya gejala berupa nekrosis, karena menurut Agrios (1997) hanya tanaman yang mempunyai reseptor terhadap toksin yang dihasilkan oleh patogen, yang akan mengalami gejala, yaitu nekrosis. Nekrosis yang terjadi pada jeruk siam Banjar dapat dilihat pada Gambar 3.

Namun demikian, penelitian ini masih perlu tindak lanjut, terutama masih perlu dilakukan pemurnian terhadap crude toxin yang dihasilkan, sehingga dapat diketahui toksin tersebut tersusun dari komponen apa saja/dari golongan apa dan akan dapat diketahui struktur kimianya. Sedangkan untuk pemanfaatan yang lebih luas, perlu penelitian tentang pengaruh faktor lingkungan terhadap stablitas toksin dan penelitian tentang hubungan antara masa inkubasi dan produksi toksin.

\section{SIMPULAN}

Dari penelitian yang dilakukan dapat diambil beberapa simpulan sebagai berikut:

1. Crude toxin yang dihasilkan oleh patogen yang diisolasi dari jeruk siam Banjar yang terserang Botryodiplodia theobromae bersifat toksik terhadap jeruk siam Banjar, jeruk irisan, jeruk nipis, jeruk purut, dan jeruk sambal, sedangkan pada jeruk bali dan sunkist toksin tidak murni tidak bersifat toksik.

2. Crude toxin yang diperoleh dihasilkan pada saat patogen berkecambah tetapi tidak dihasilkan lagi setelah patogen masuk dan berkembang biak dalam jaringan tanaman inang. Oleh karena itu, toksin ini tidak diproduksi pada bagian tanaman sakit. 

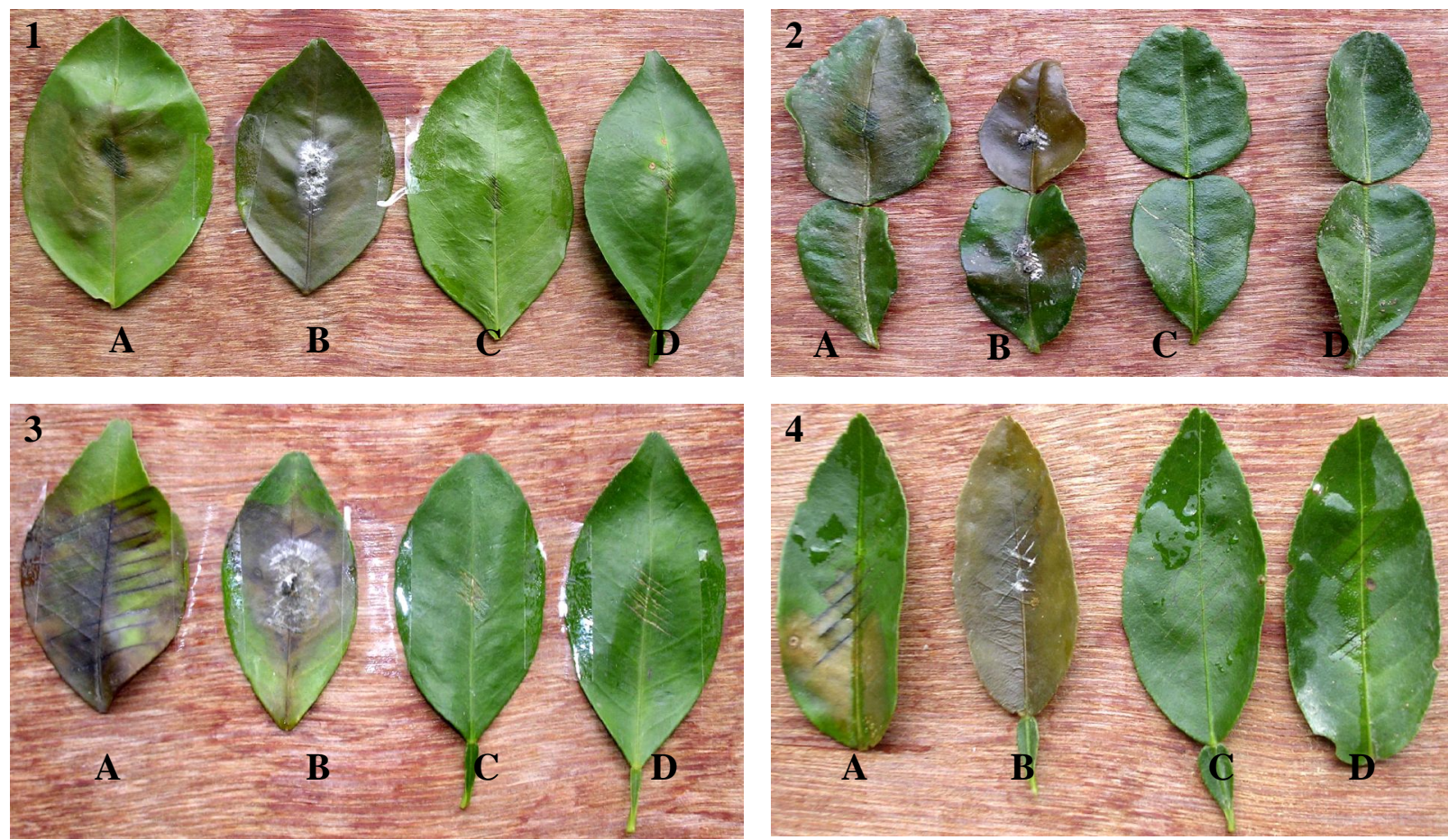

Gambar 4. Uji toksisitas crude toxin dari Botryodiplodia theobromae. 1. Jeruk irisan 2. Jeruk purut 3. Jeruk sambal 4. Jeruk nipis. A. Toksin B. Isolat C. PDB D. Aquadest (pengamatan dilakukan 5 hari setelah perlakuan)
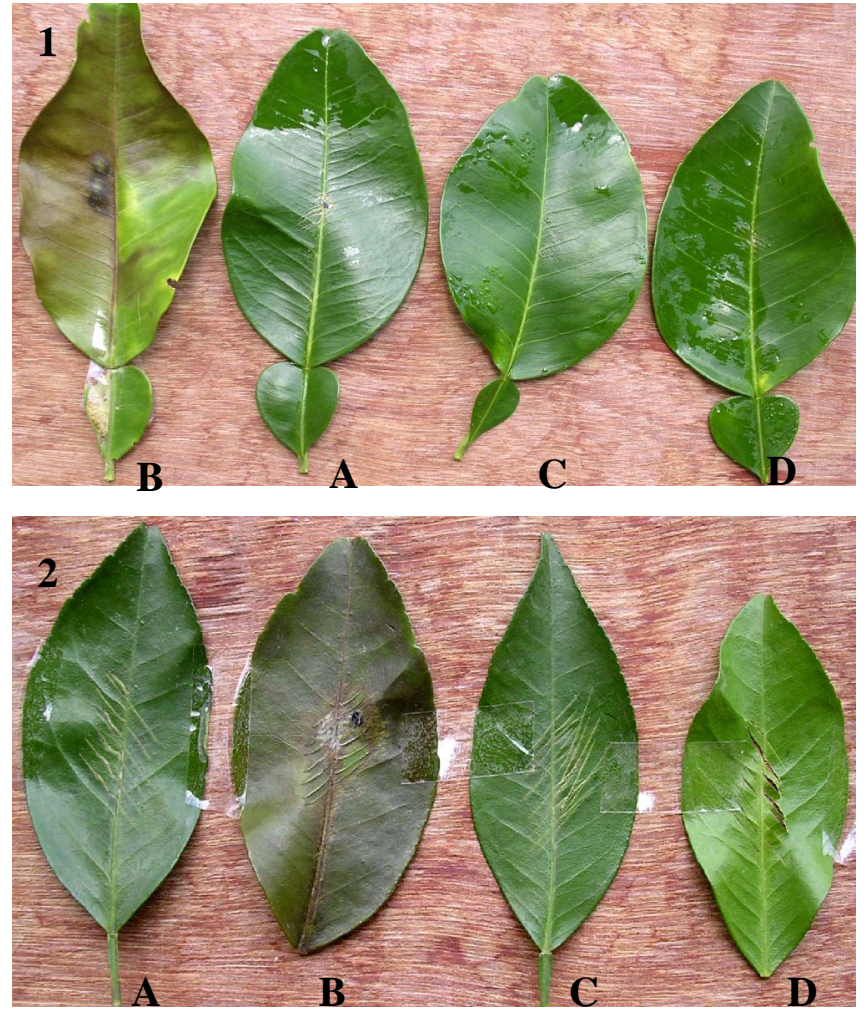

Gambar 5. Uji toksisitas crude toxin dari Botryodiplodia theobromae. 1. Jeruk bali 2. Jeruk sunkist A. Toksin B. Isolat C. PDB D. Aquadest (pengamatan dilakukan 5 hari setelah perlakuan) 


\section{SANWACANA}

Penelitian ini merupakan bagian dari penelitian Fundamental Tahun 2007. Penulis mengucapkan terima kasih kepada Direktorat Jenderal Penelitian dan Pengabdian kepada Masyarakat (DP2M), Dirjen Dikti, atas dukungan dananya.

\section{DAFTAR PUSTAKA}

Agrios, G.N. 1997. Plant Pathology. Academic Press, New York.

Balai Proteksi Tanaman Pangan dan Hortikultura Kalimantan Selatan. 2003. Laporan Tahunan Balai Proteksi Tanaman Pangan dan Hortikultura Tahun 2002/2003.

Barnett, H.L. \& H.B. Hunter. 1972. Illustrated Genera of Imperpect Fungi. Bergess Publ. Co. USA.

Dewey, R.E., J.N. Siedow, D.H. Tomothy, \& C.S. Leving III. 1988. A 13-kilodalton maize mitochondrial protein in E. coli confers sensitivity to Bipolaris maydis toxin. Science 239 : 293295.

Flor, A.H. 1971. Current status of the gen-for-gen concept. Annu. Rev. Phytophatol. 9: 275-296.

Huang, S.L. \& K. Kohmoto. 1991. A simple method for isolating single fungal spores. Bull. Fac. Agric. Tottori Univ. 44 : 1-3 (in Japanese).

Kardin, M.K. 1977. Rhizoctonia spp. isolated from rice. Prosiding Kongres XIV dan Seminar Nasional, PFI. Volume II, Palembang, Indonesia.

Khan, F.U., B. Nelson, \& T. Helms. 1992. Biocontrol activity and pathogenicity of binucleate Rhizoctonia on soybean (Abtr.) Phytopathology $82: 1156$.

Kohmoto, K. \& H. Otani. 1991. Host recognition by toxigenic plant pathogens. Experintia 47 : 755764.
Kohmoto, K. 1992. Determination of host-selective toxins. In: Modern Methods of Plant Analysis New Series, Vol.13. Plant Toxin Analysis, H.F.Linsken \& J.F. Jackson (eds.), Springer-Verlag, Berlin. hlm. 51-73.

Kohmoto, K., Y. Itoh, N. Shimomura, Y. Kondoh, H. Otani, M. Kodama, S. Nishimura, \& S. Nakatsuka. 1993. Isolation and biological activities of two host-specific toxins from the tangerin pathotype of Alternaria alternata. Phytopathology 83 : 495-502.

Nishimura, S. \& K. Kohmoto. 1983. Host-specific toxins and chemical structures from Alternaria species. Annu. Rev. Phytopathol. 21 : 87-116.

Ogoshi, A. 1985. Anastomosis and intraspecific groups of Rhizoctonia solani and binucleate Rhizoctonia. Phytopathology Bras. 10 : 371390.

Otani, H., K. Kohmoto, \& M. Kodama. 1995. Alternaria toxins and their effects on host plants. Can. J. Bot. 73 : S453-S458.

Salamiah, Y. Fukumasa-Nakai, H. Akamatsu, H. Otani, K. Kohmoto, \& M. Kodama. 2001a. Genetic analysis of pathogenicity and host-specific toxin production of Alternaria alternata tomato pathotype by protoplast fusion. J. Gen. Plant Pathol. 67 : 7-14.

Salamiah, H. Akamatsu, Y. Fukumasa-Nakai, H. Otani, $\&$ M. Kodama. 2001b. Construction and genetic analysis of hybrid strains between the apple and tomato pathotype of Alternaria alternata by protoplast fusion. J. Gen. Plant Pathol. 67: 97105.

Salamiah \& M. Melanie. 2004. Pengujian kemampuan tiga macam pestisida botanis dalam mengendalikan penyakit kulit Diplodia pada jeruk. Unpublish. 
Salamiah \& N. Rahmah. 2004. Pemanfaatan agens antagonis Trichoderma spp. dan Gliocladium untuk mengendalikan penyakit kulit Diplodia pada jeruk. Unpublish.

Scheffer, R.P. \& R.S. Livingston. 1984. Host-selective toxins and their role in plant diseases. Science $223: 17-21$.

Singh, P. 2000. Host-specific SV-toxins produced by Stemphylium vesicarium causing brown spot of European pear. Thesis Ph.D. Course. United Graduate School of Agriculture Science. Tottori University, Japan.
Walton, J.D. 1996. Host-selective toxins : agents of compatibility. Plant Cell 8 : 1723-1733.

Yoder, O.C. 1980. Toxins in pathogenesis. Annu. Rev. Phytopathol. 18 : 103-129. 